\title{
Inhibition of Toll-Like Receptor 2-Mediated Interleukin-8 Production in Cystic Fibrosis Airway Epithelial Cells via the $\alpha 7$-Nicotinic Acetylcholine Receptor
}

\author{
Catherine M. Greene, Hugh Ramsay, Robert J. Wells, Shane J. O’Neill, \\ and Noel G. McElvaney \\ Department of Medicine, RCSI Education and Research Centre, Beaumont Hospital, Dublin 9, Ireland \\ Correspondence should be addressed to Catherine M. Greene, cmgreene@rcsi.ie
}

Received 1 December 2009; Accepted 19 January 2010

Academic Editor: Philipp M. Lepper

Copyright (C) 2010 Catherine M. Greene et al. This is an open access article distributed under the Creative Commons Attribution License, which permits unrestricted use, distribution, and reproduction in any medium, provided the original work is properly cited.

\begin{abstract}
Cystic Fibrosis (CF) is an inherited disorder characterised by chronic inflammation of the airways. The lung manifestations of CF include colonization with Pseudomonas aeruginosa and Staphylococcus aureus leading to neutrophil-dominated airway inflammation and tissue damage. Inflammation in the CF lung is initiated by microbial components which activate the innate immune response via Toll-like receptors (TLRs), increasing airway epithelial cell production of proinflammatory mediators such as the neutrophil chemokine interleukin-8 (IL-8). Thus modulation of TLR function represents a therapeutic approach for CF. Nicotine is a naturally occurring plant alkaloid. Although it is negatively associated with cigarette smoking and cardiovascular damage, nicotine also has anti-inflammatory properties. Here we investigate the inhibitory capacity of nicotine against TLR2and TLR4-induced IL-8 production by CFTE29o- airway epithelial cells, determine the role of $\alpha 7$-nAChR (nicotinic acetylcholine receptor) in these events, and provide data to support the potential use of safe nicotine analogues as anti-inflammatories for CF.
\end{abstract}

\section{Introduction}

$\mathrm{CF}$ is an autosomal recessive inherited disorder characterised by mutations in the gene encoding the Cystic Fibrosis Transmembrane Conductance Regulator (CFTR) protein. It is the most common inherited metabolic disorder among Caucasians of European descent, with the most common defect being the $\Delta$ F508CFTR mutation which causes the protein to fold aberrantly and accumulate in the endoplasmic reticulum of CFTR-producing cells. This leads to decreased apical expression of CFTR in airway epithelial cells, impaired $\mathrm{Cl}^{-}$conductance, $\mathrm{Na}^{+}$hyperabsorption, mucus hypersecretion, impaired mucociliary clearance, and colonization with microorganisms [1].

The lung manifestations of $\mathrm{CF}$ are characterised by chronic infection and neutrophil-dominated airway inflammation and are initiated by proinflammatory microbial stimuli culminating in increased airway epithelial cell production of proinflammatory mediators, including the neutrophil chemokine interleukin-8 (IL-8) [2]. Toll-like receptors (TLRs) play an important role in these events [3].

TLRs respond to microbial antigens and initiate signalling cascades that culminate in proinflammatory gene expression, principally via activation of the transcription factors $N F \kappa B$ and the IRFs [4-6]. TLRs are present on a variety of cell types, including both immune cells and epithelial cells within the lung [7]. The expression and function of ten members of the human TLR family have been partially or fully characterized to date. TLRs expressed by airway epithelial cells contribute to the pulmonary immune response by regulating the production and secretion of diffusible chemotactic molecules, mucins, antimicrobial peptides, and cytokines and by enhancing cell surface adhesion molecules expression [3, 8-23]. A plethora of proinflammatory cytokines is regulated by TLR activation in airway epithelial cells; TNF $\alpha$ and IL- 6 can be induced by TLR2, TLR4, and TLR9 agonists, for example, [3, 10, $21,24]$. IL-8 is a potent neutrophil chemoattractant. It 
is a particularly important cytokine in the neutrophildominated CF lung. In the context of CF and airway epithelial cells, various TLR agonists have been shown to promote proinflammatory gene transcription (reviewed in [7]). Chronic activation of TLRs can lead to overproduction of these factors and ultimately have a deleterious effect on pulmonary function and homeostasis.

Of all the TLRs, TLR2 has emerged as the principal receptor responsible for orchestrating changes in proinflammatory gene expression in airway epithelial cells $[11,16$, $17,19,20]$. TLR2 is activated by the broadest repertoire of agonists including lipoteichoic acids, peptidoglycan, di- and tri-acylated lipopeptides from Gram-positive and/or Gramnegative bacteria, protozoans, mycobacteria, yeasts, and mycoplasma and is interesting amongst the TLR family in that it can heterodimerize with other TLRs to confer responsiveness to these diverse ligands. In conjunction with TLR1 it recognizes triacylated lipopeptides and Gram-positive lipoteichoic acid; whereas with TLR6 it can respond to diacylated lipopeptides such as MALP-2 from mycoplasma. Due to the presence of multiple potential TLR2 agonists in the CF lung, this environment represents a milieu where TLR2 is likely to be chronically activated [25]. Thus modulation of TLR2 function represents a therapeutic target for CF.

Nicotine is a naturally occurring plant alkaloid. Although it is negatively associated with cigarette smoking, addiction, and cardiovascular damage, nicotine also has therapeutic properties and is a promising new treatment for chronic inflammatory disorders. For example nicotine is prescribed to treat the overt inflammation of gut epithelial cells in ulcerative colitis [26] and is reported to have potential therapeutic benefit for neuroinflammatory conformational disorders including Alzheimer's and Parkinson's diseases [27]. Interestingly TLRs have been shown to play a role in the disordered inflammatory response in ulcerative colitis (UC) [28].

Nicotine exerts a variety of biological effects via the nicotinic acetylcholine receptors (nAChRs), for example, inhibiting LPS-induced TNF $\alpha$, IL-1, and IL-6 in rat peritoneal macrophages, iNOS in murine macrophages or IL18 in human monocytes [29-31]. nAChRs are ligand-gated cation channels that comprise a pentameric transmembrane complex of multiple $\alpha(1-10), \beta(1-4), \gamma, \delta$ or $\varepsilon$ subunits, each of which has four transmembrane spanning domains that form the ion channel [32]. $\alpha(2-6)$ and $\beta(2-4)$ can form hetero-oligomeric nAChRs, whereas $\alpha(7-9)$ subunits form homo-oligomers. It is the $\alpha$ subunit that contains the ligand binding domain. The human $\alpha 7$ subunit is $\sim 50 \mathrm{kDa}$ and is composed of 502 amino acids and a 22-residue signal peptide [32]. Studies of the anti-inflammatory effects of nicotine implicate $\alpha 7-\mathrm{nAChR}$ as the receptor involved [27, $29,31]$. The $\alpha 7$-nAChR has been shown to be present on human bronchial epithelial cells [33]. However, it remains to be determined if the $\alpha 7$ receptor is present on CF airway epithelial cells.

In this study we investigate the effect of nicotine on IL-8 production by a CF airway epithelial cell line (CFTE29o-) in response to a range of TLR2 and TLR4 agonists. We assess expression of $\alpha 7$-nAChR in these cells and use general and specific nAChR antagonists to determine the role of $\alpha 7$ -
nAChR in nicotine-mediated inhibition of TLR2-induced IL-8 expression.

\section{Materials and Methods}

2.1. Cell Cultures and Treatments. CFTE29o- cells are a $\Delta$ F508 homozygous tracheal epithelial cell line. These were obtained as a gift from D. Gruenert (California Pacific Medical Center Research Institute, San Francisco, CA). The cells were cultured in EMEM (Invitrogen Life Technologies) supplemented with $10 \%$ foetal calf serum (FCS) at $37^{\circ} \mathrm{C}$ in a humidified atmosphere in $5 \% \mathrm{CO}_{2}$. Twenty-four hours before agonist treatment, the cells were washed with serumfree EMEM and placed under serum-free conditions or in medium with $1 \%$ FCS for LPS treatments.

Stock nicotine (Sigma, $1 \mathrm{mg} / \mathrm{mL}$ or $6.2 \mathrm{mM}$ in methanol) was diluted in serum-free EMEM. Pseudomonas LPS, peptidogylcan, zymosan, phorbol myristic acetate (PMA), d-tubocurarine, and $\alpha$-bungarotoxin were from Sigma; triacylated lipopeptide (palmitoyl-Cys((RS)-2,3di((palmitoyloxy)-propyl)-Ala-Gly-OH) ( $\left.\mathrm{Pam}_{3}\right)$ was from Bachem.

2.2. IL-8 Protein Production. Cells $\left(1 \times 10^{5}\right)$ were left untreated, or in some experiments pretreated with $\mathrm{d}$ tubocurarine or $\alpha$-bungarotoxin as indicated, prior to addition of nicotine at various concentrations for 1 hour at $37^{\circ} \mathrm{C}$. Cells were then left untreated or stimulated with TLR2 or TLR4 agonists or PMA for 24 hours at $37^{\circ} \mathrm{C}$ as indicated. IL-8 protein concentrations in the cell supernatants were determined by sandwich ELISA (R \& D Systems). All assays were performed in triplicate.

2.3. Cell Proliferation Assay. CFTE29o- cells $\left(1 \times 10^{5} / \mathrm{mL}\right)$ were left untreated or stimulated with increasing doses of nicotine (in triplicate) for 24 hours. Following this, the supernatant in each well was replaced with $500 \mu \mathrm{L}$ of serum free medium and $100 \mu \mathrm{L}$ of proliferation assay reagent (CellTiter 96 Aqueous One Solution Cell Proliferation Assay) and the samples were incubated for a further 3 hours at $37^{\circ} \mathrm{C}$. Samples $(120 \mu \mathrm{L})$ were transferred from each well of the 24 well plates to a 96-well plate in duplicate. The plate was read at $490 \mathrm{~nm}$. The effect of the blank well was subtracted and change in cell proliferation was measured as a percentage change from the untreated cells.

2.4. Laser-Scanning Cytometry. Cells $\left(1 \times 10^{5}\right)$ were grown in a four-well chamber slide, washed with PBS, Fc-blocked for 15 minutes at room temperature with 1\% BSA (SigmaAldrich), then labelled with anti- $\alpha 7$-nAChR primary antibody (Abcam) for 30 minutes at $4^{\circ} \mathrm{C}$. Following three washes, cells were incubated with $10 \mu \mathrm{g} / \mathrm{mL}$ FITC-labelled secondary antibody (antirabbit $\mathrm{F}(\mathrm{ab})_{2}$ FITC (DakoCytomation)) for 30 minutes at $4^{\circ} \mathrm{C}$. Cells were counterstained with propidium iodide (PI) (Molecular Probes), and laser-scanning cytometry (LSC) (Compucyte) was used to quantify cell surface $\alpha 7$-nAChR expression. LSC is slide-based cytometry which enables the detection and quantification of cell surface 


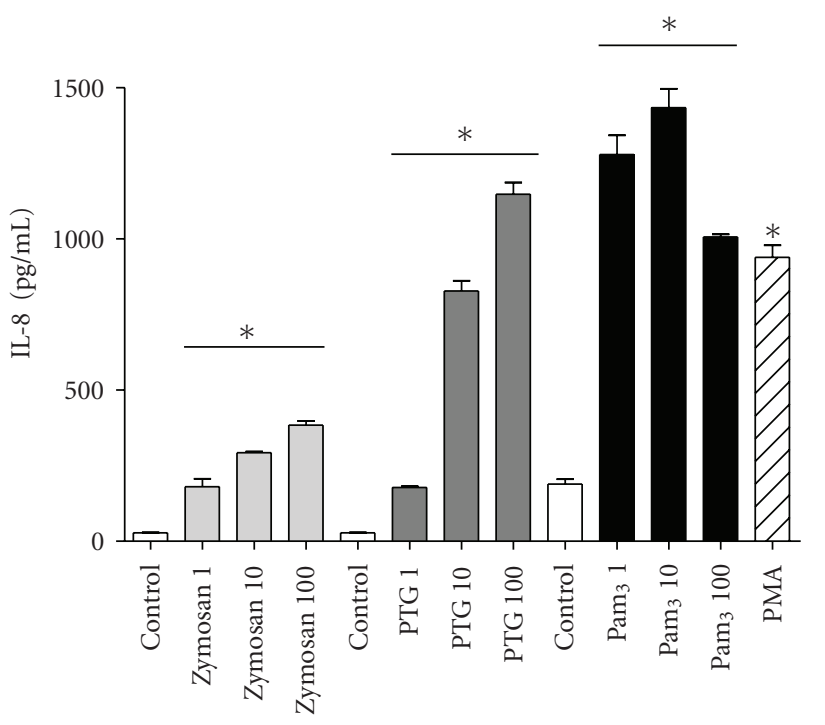

(a)

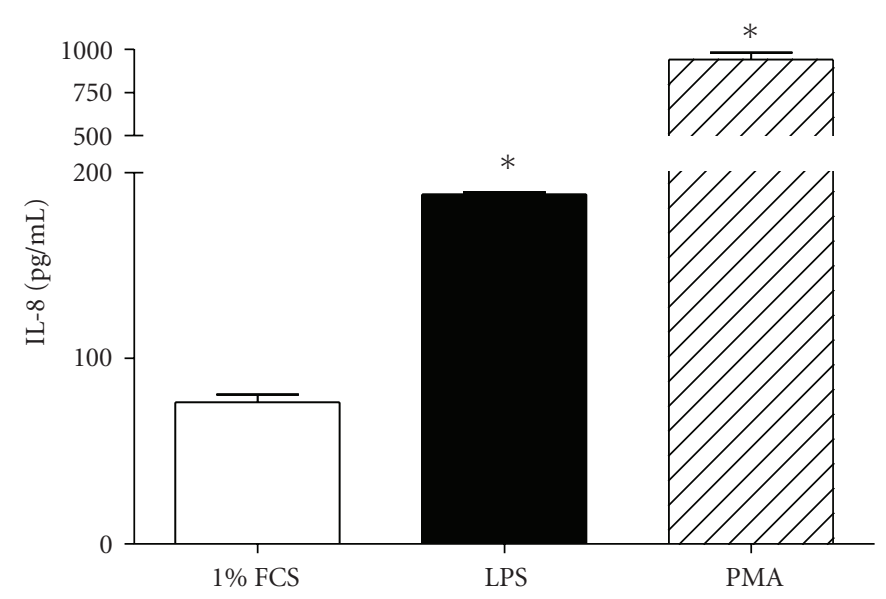

(b)

Figure 1: Effect of TLR2 and TLR4 agonists on IL-8 production in CFTE29o- cells. Triplicate samples of CFTE29o- cells $\left(1 \times 10^{5} / \mathrm{mL}\right)$ were left untreated or treated with (a) $1-100 \mu \mathrm{g} / \mathrm{mL}$ zymosan, PTG and $\mathrm{Pam}_{3}$, or PMA $(50 \mathrm{ng} / \mathrm{mL}$ ) in serum-free media for 24 hours, or (b) Pseudomonas LPS $(10 \mu \mathrm{g} / \mathrm{mL})$ or PMA $(50 \mathrm{ng} / \mathrm{mL})$ in medium supplemented with $1 \%$ FCS for 24 hours. Levels of IL-8 in supernatants were measured by ELISA and values are expressed in $\mathrm{pg} / \mathrm{mL}\left({ }^{*} P \leq .05\right.$ versus control $)(n=7)$.

expressed (or intracellular markers if a permeabilisation reagent is used) on cytospun or adherent cells without the need for trypsinization, a process which can potentially remove some receptors $[3,24,34-40]$. Cells are stained with PI enabling detection of all cell nuclei and an FITC-labelled antibody directed against the receptor of interest allows quantification of the target on the total cell population. FITC and PI cellular fluorescence of at least 2000 cells were measured. $\alpha 7-\mathrm{nAChR}$ expression was quantified using CompuCyte software on the basis of integrated green fluorescence. An appropriate rabbit antimouse isotype antibody was used as a control (DakoCytomation).

2.5. Statistical Analysis. Data were analysed with GraphPad Prism 4.0 software (GraphPad). Results are expressed as mean \pm SE and were compared by Mann Whitney $U$-test. Differences were considered significant when the $P$-value was $\leq .05$.

\section{Results}

3.1. TLR2 and TLR4 Agonists Induce IL-8 Production from CFTE29o-Cells. The effect of the TLR agonists zymosan, peptidoglycan (PTG), triacylated lipopeptide $\left(\mathrm{Pam}_{3}\right)$, and Pseudomonas LPS on IL-8 production by CFTE29o- cells was quantified by ELISA (Figure 1). Each of the TLR2 agonists dose dependently increased IL-8 production by CFTE29ocells compared to untreated cells after 24 hours treatment (Figure 1(a)). The zymosan preparation was found to be contaminated with intact yeast particles so for subsequent experiments only PTG or $\mathrm{Pam}_{3}$, at $5 \mu \mathrm{g} / \mathrm{mL}$ and $1 \mu \mathrm{g} / \mathrm{mL}$, respectively, were used. LPS treatment $(10 \mu \mathrm{g} / \mathrm{mL}, 24$ hours $)$ also significantly increased IL-8 expression by CFTE29ocells (Figure $1(\mathrm{~b}))$. PMA $(50 \mathrm{ng} / \mathrm{mL})$ is a known inducer of IL- 8 and was used as a positive control.

3.2. Nicotine Inhibits Peptidoglycan- and Triacylated Lipopeptide-Induced IL-8 Production by CFTE29o- Cells. We next investigated the effect of nicotine on TLR2 agonist-induced IL- 8 production (Figure 2). As before PTG treatment $(5 \mu \mathrm{g} / \mathrm{mL}, 24$ hours) led to a significant increase in IL-8 production from CFTE29o- cells compared to untreated controls. This response was significantly reduced in the presence of nicotine at concentrations of 10 and $50 \mu \mathrm{M}$. The vehicle control had no effect at these doses however at a dose equivalent to $100 \mu \mathrm{M}$ nicotine, vehicle significantly impaired PTG-induced IL- 8 production (data not shown). For this reason we carried out all subsequent experiments using nicotine at concentrations up to $50 \mu \mathrm{M}$.

Figure 3 shows that nicotine also significantly inhibited Pam $_{3}$-induced IL-8 expression from CFTE29o- cells at 10 and $50 \mu \mathrm{M}$.

3.3. Nicotine Does Not Inhibit LPS-Induced IL-8 Production by CFTE29o-Cells. Next the effect of nicotine on IL-8 production induced by the TLR4 agonist Pseudomonas LPS was assessed. These assays were performed in the presence of $1 \%$ FCS to facilitate LPS-TLR4 signalling. Figure 4 shows that LPS-induced IL-8 production was not significantly inhibited by pretreatment with nicotine at concentrations of $1-50 \mu \mathrm{M}$.

3.4. Effect of Nicotine on CFTE29o- Proliferation. Nicotine has known antiapoptotic effects in a variety of cells [4144]. However in order to determine that nicotine's ability 


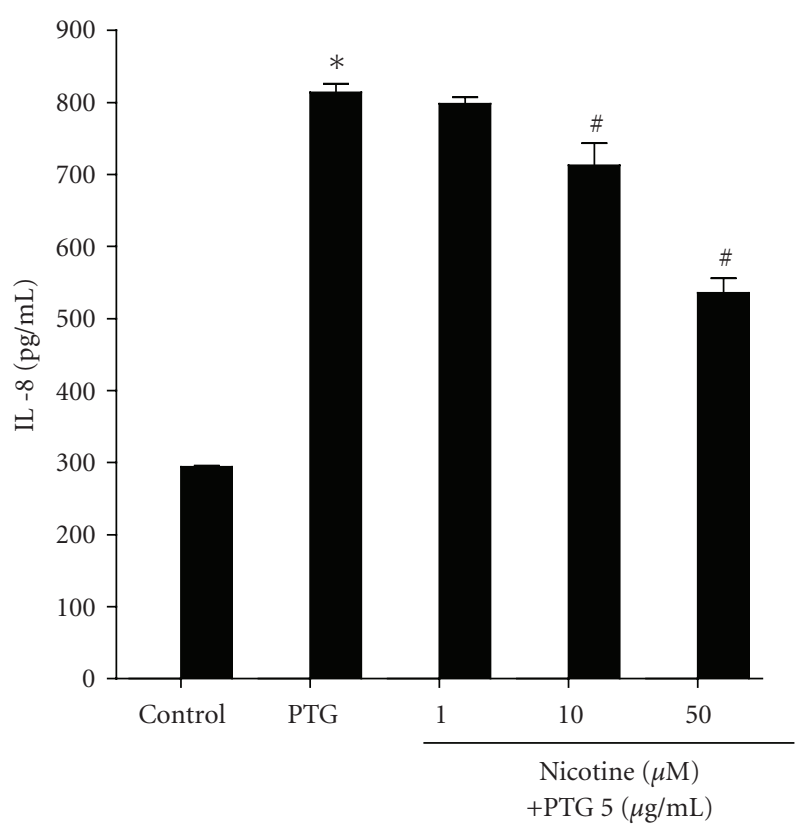

Figure 2: Nicotine inhibits PTG-induced IL-8 protein expression at concentrations of 10 and $50 \mu \mathrm{M}$. CFTE29o- cells $\left(1 \times 10^{5} / \mathrm{mL}\right)$ were stimulated with increasing doses of nicotine $(0-50 \mu \mathrm{M})$ for 1 hour. These samples were left untreated (control) or treated with PTG $(5 \mu \mathrm{g} / \mathrm{mL}, 24$ hours $)$ as indicated. Levels of IL- 8 in supernatants were measured by ELISA. Assays were performed in triplicate $(*$ and ${ }^{\#} P \leq .05, *$ versus control, \# versus PTG) $(n=6)$.

to decrease TLR2-induced IL-8 production was not being mediated by increased cell death or apoptosis, the effect of nicotine on CFTE29o- cell proliferation was tested. Figure 5 shows that over a range of concentrations up to $50 \mu \mathrm{M}$, nicotine was nontoxic to CFTE29o- cells and at $10 \mu \mathrm{M}$ nicotine has a significant protective effect and actually promoted cell survival $(* P=.0286)$.

3.5. CFTE29o- Cells Express the $\alpha 7-n A C h R$. Nicotine is known to exert an anti-inflammatory effect through the $\alpha 7$-nAChR [45]. We used laser scanning microscopy to examine cell surface expression of $\alpha 7$-nAChR on CFTE29ocells. Figure 6 illustrates that CFTE29o- cells express the $\alpha 7$ $\mathrm{nAChR}$; the histogram in Figure 6(a) shows clear detection of $\alpha 7$-nAChR with an anti- $\alpha 7$-nAChR antibody (solid) compared to an isotype control antibody (clear). In Figure 6(b) the median channel fluorescence (MCF) emitted by the FITC-linked anti- $\alpha 7$-nAChR antibody is significantly greater than that of the isotype antibody $(163,710 \pm 31,788$ versus $325,680 \pm 55,554 \mathrm{MCF}, P=.0011)$.

3.6. $\alpha 7-n A C h R$ Mediates Nicotine's Inhibitory Effect on TLR2Induced IL-8 Production in CFTE29o- Cells. Finally we investigated whether nicotine mediates its anti-inflammatory effects via $\alpha 7-\mathrm{nAChR}$ in CF airway epithelial cells. To do this we employed the use of d-tubocurarine, a broadrange nAChR inhibitor, and $\alpha$-bungarotoxin, a specific $\alpha 7$ $\mathrm{nAChR}$ inhibitor. For these experiments we used nicotine at
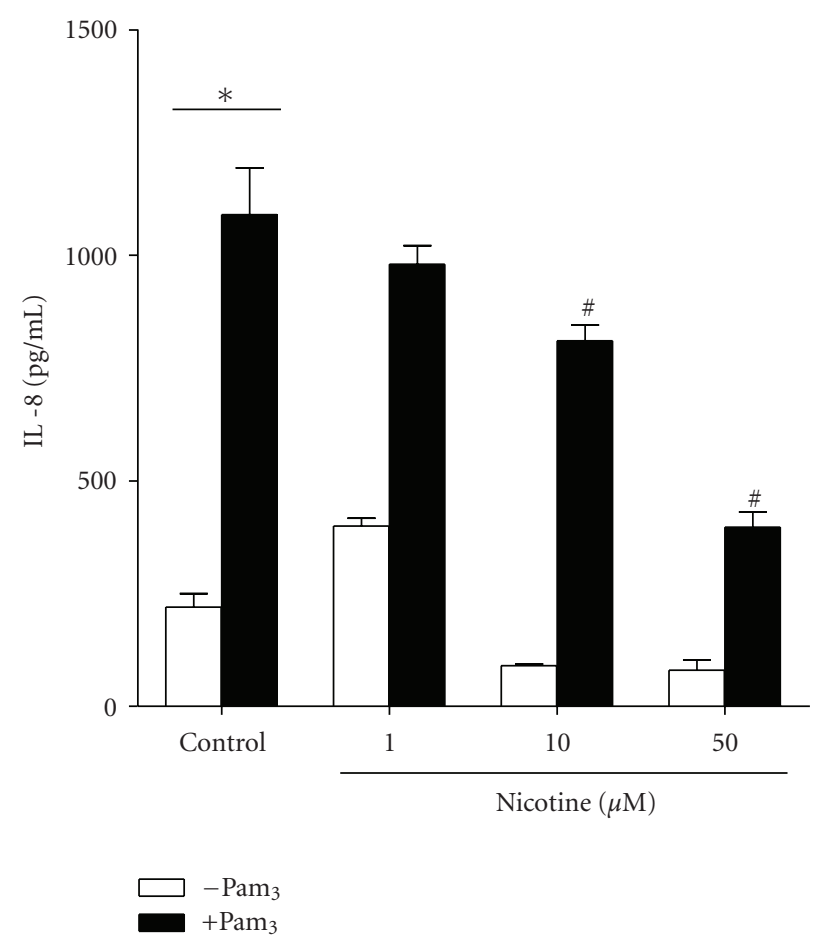

Figure 3: Nicotine inhibits $\mathrm{Pam}_{3}$-induced IL-8 production in a dosedependent manner. CFTE29o- cells $\left(1 \times 10^{5} / \mathrm{mL}\right)$ were left untreated or stimulated with increasing doses of nicotine $(0-50 \mu \mathrm{M})$ for 1 hour then left untreated or stimulated with $\mathrm{Pam}_{3}(1 \mu \mathrm{g} / \mathrm{mL}, 24$ hours) as indicated. Levels of IL-8 in supernatants were measured by ELISA and values are expressed in $\mathrm{pg} / \mathrm{mL}\left(*\right.$ and ${ }^{*} P \leq .05, *$ versus control, \# versus $\left.\mathrm{Pam}_{3}\right)$. Assays were performed in triplicate $(n=5)$.

$10 \mu \mathrm{M}$ and as before this dose significantly inhibited $\mathrm{Pam}_{3}-$ induced IL-8 protein production (Figure 7). Pretreatment with either antagonist for 1 hour had no effect on nicotine's ability to inhibit the TLR2 response (data not shown). However pretreatment for $16 \mathrm{~h}$ with the broad range $\mathrm{nAChR}$ antagonist d-tubocurarine reversed the inhibitory effect of nicotine on $\mathrm{Pam}_{3}$-induced IL-8 expression, with IL-8 levels not significantly different from those induced by $\mathrm{Pam}_{3}$ alone. Similarly $16 \mathrm{~h}$ pretreatment of CFTE29o- cells with $\alpha$ bungarotoxin $(1 \mu \mathrm{M})$ abrogated nicotine's ability to decrease expression of IL-8 in response to $\mathrm{Pam}_{3}$. These data implicate $\alpha 7$-nAChR in nicotine's anti-TLR2 effect.

\section{Discussion}

Whilst inflammation in the CF lung is a neutrophildominated process, the airway epithelium plays a key role in the regulation of neutrophil recruitment via TLR-mediated changes in gene and protein expression [3]. Here we show that CF airway epithelial cells express $\alpha 7-\mathrm{nAChR}$ and respond to nicotine by inhibiting TLR2 agonist-induced IL- 8 expression. This novel finding is of particular interest with respect to $\mathrm{CF}$, as the $\mathrm{CF}$ lung is a milieu rich in potential TLR2 agonists and because TLR2 is the predominant TLR 


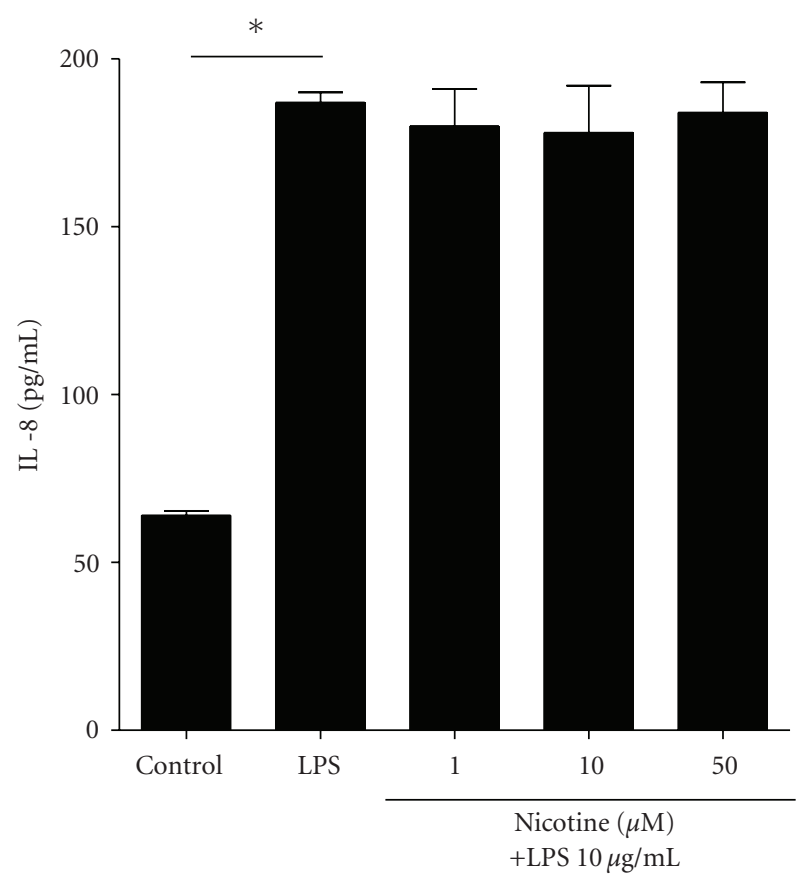

Figure 4: No effect of nicotine on LPS-induced IL-8 protein production in CFTE29o- cells. CFTE29o- cells $\left(1 \times 10^{5} / \mathrm{mL}\right)$ were left untreated or stimulated with increasing doses of nicotine $(0$ $50 \mu \mathrm{M})$ for 1 hour. Following this, samples were either left untreated or treated with Pseudomonas LPS ( $10 \mu \mathrm{g} / \mathrm{mL}, 24$ hours). Levels of IL8 in supernatants were measured by ELISA and values are expressed in $\mathrm{pg} / \mathrm{mL}\left({ }^{*} P \leq .05\right)$. Assay was performed in triplicate $(n=4)$.

expressed on the surface of lung epithelial cells in vivo $[11,16,17,19,20,25]$.

The mechanism by which nicotine can exert its antiinflammatory effects has been reported to include targeting $\mathrm{NF} \kappa \mathrm{B}$ and AP1 [46, 47]; the IL-8 gene is regulated by both of these transcription factors. For example, nicotine in cigarette smoke extract can inhibit transcription of LPS-induced IL-1, IL-8, and $\mathrm{PGE}_{2}$ in activated macrophages through inhibition of the NF $\kappa$ B pathway. Although we did not observe inhibition of LPS-induced IL-8 expression in CF airway epithelial cells, others have reported that nicotine can inhibit LPSinduced NF $\kappa$ B DNA binding and transcriptional activity. Indeed several studies have linked the anti-inflammatory function of nAChRs to the NF $\kappa B$ pathway [46, 48-53]. Yoshikawa et al. [54] further reported that the mechanism by which nicotine impairs $\mathrm{NF} \kappa \mathrm{B}$ activation in human peripheral monocytes is via inhibition of phosphorylation of $\mathrm{I} \kappa \mathrm{B}$. Given that TLR4 and TLR2 share the same signalling pathways, it is likely that nicotine also inhibits TLR2-induced IL-8 expression by targeting NF $\kappa$ B and possibly AP1 [4-6].

The anti-inflammatory effects of nicotine can be mediated via $\alpha 7$-nAChR [45], and our studies clearly implicate $\alpha 7$-nAChR in nicotine's anti-TLR2 activity in CF airway epithelial cells. A range of nAChRs has been shown to be present on human epithelial cells, including $\alpha 7-, \alpha 3-$, and $\alpha 3 \beta 4$-subtypes $[33,55]$. Normal bronchial epithelial

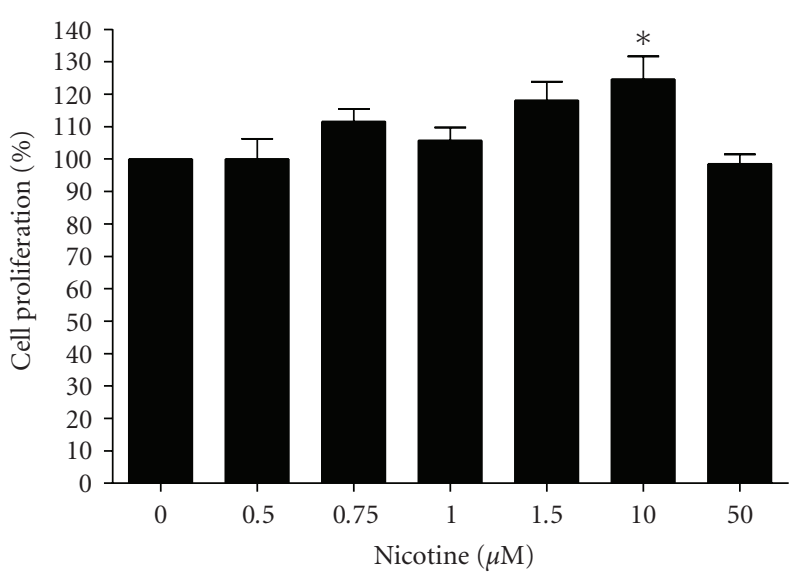

Figure 5: Nicotine does not increase CFTE cell death but increases cell survival at certain concentrations. CFTE29o- cells $\left(1 \times 10^{5} / \mathrm{mL}\right)$ were left untreated or stimulated with increasing doses of nicotine (in triplicate) for 24 hours. Cell proliferation was quantified and values are expressed as a percentage change from the untreated cells $\left({ }^{*} P \leq .05\right)$.

cells express $\alpha 7$-nAChR. Our studies have detected $\alpha 7$ nAChR on CF tracheal epithelial cells for the first time and show that specific inhibition of $\alpha 7-\mathrm{nAChR}$ using $\alpha$ bungarotoxin (a 75 amino acid peptide from Bungarus multicinctus venom) abrogates nicotine's ability to impair $\mathrm{Pam}_{3}$-induced IL- 8 protein production. Thus $\alpha 7$-nAChR may represent a new therapeutic target for CF. Agonists of $\alpha 7$-nAChR have previously been proposed for the treatment of inflammatory diseases via their ability to reduce TNF $\alpha$ release from macrophages. For example in vivo treatment with nicotine can inhibit TNF $\alpha$-induced HMGB1 secretion and has a proven therapeutic benefit in models of sepsis [48]. In these studies nicotine did not affect levels of total or phosphorylated versions of ERK, JNK, or p38 MAPK, rather the observed effects occurred directly via $\alpha 7$-nAChRmediated blockade of $\mathrm{NF} \kappa \mathrm{B}$.

A major drawback to the potential use of nicotine as a therapeutic agent is its negative side effects which are associated with addiction, cardiovascular disease, hypertension, cancer, reproductive and gastrointestinal disorders. However, nicotine analogues exist that lack addictive or damaging side effects but retain desirable anti-inflammatory and cognitive-enhancing properties. Indeed the objective in developing nicotine analogues is the discovery of novel drugs that feature the beneficial actions of nicotine whilst eschewing its side-effect profile [56, 57]. The addictive properties of nicotine are mediated via the $\beta 2$-containing nAChR subtypes, hence compounds that are selective for the $\alpha 7$-nAChR - the receptor that mediates nicotine's antiinflammatory effects - are attractive as potential therapeutic agents. Varenicline is a partial agonist of the $\alpha_{4} \beta_{2}$ receptor and a full agonist of $\alpha 7-\mathrm{nAChR}$ that is currently used as a smoking-cessation therapy. Given its nAChR affinity, unlike nicotine, it lacks addictive effects but retains antiinflammatory benefits [58]. Thus evaluation of the antiinflammatory properties of varenicline for $\mathrm{CF}$ would be worthy of further study. 


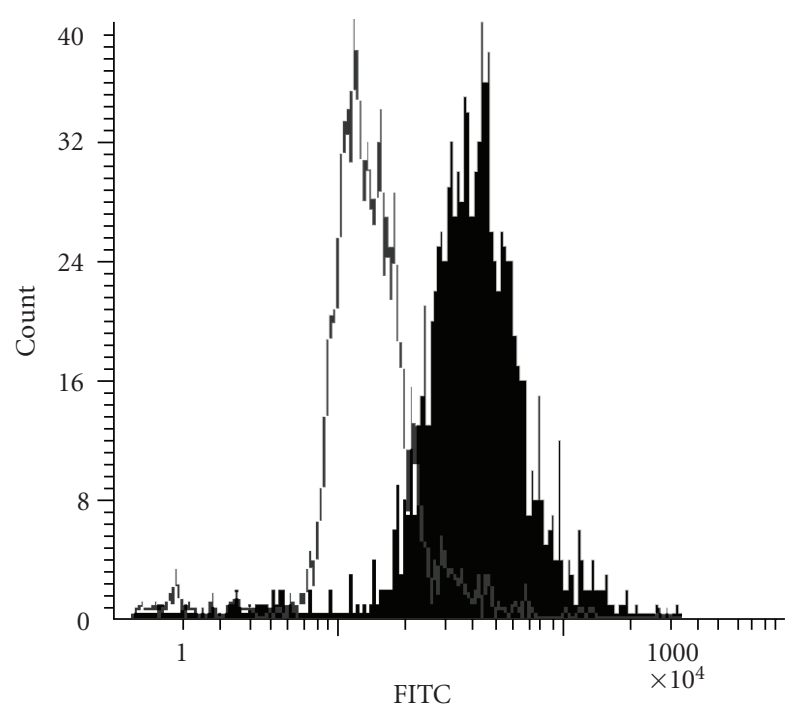

(a)

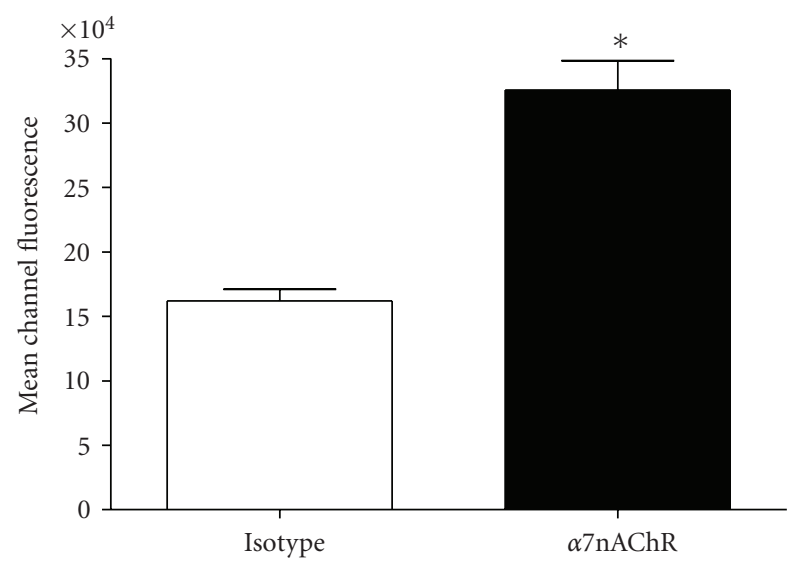

(b)

FIGURE 6: CFTE29o- cells express the $\alpha 7-n A C h R$. CFTE29o- cells $\left(1 \times 10^{5} / \mathrm{mL}\right)$ were grown in chamber slides, Fc-blocked, and labelled with FITC-conjugated anti- $\alpha 7-\mathrm{nAChR}$ or isotype control antibodies. Cells were counterstained with PI, and $\alpha 7-\mathrm{nAChR}$ surface expression was quantified by laser-scanning microscopy. (a) Representative histogram of FITC fluorescence comparing isotype (clear) and anti- $\alpha 7-\mathrm{nAChR}$ (solid) antibody-labelled samples. (b) Histogram showing median channel fluorescence \pm SEM $\left({ }^{*} P \leq\right.$ $.05, n=6)$.

Notwithstanding the novelty of this study the observations are limited somewhat by the fact that only a single CF epithelial cell line was used, cytokines other than IL-8 were not measured and nicotine analogues were not tested. It will also be important to explore in greater detail the mechanism by which nicotine achieves its anti-inflammatory effect in $\mathrm{CF}$ epithelium. These questions will form the basis of future studies.

In conclusion the findings of this study indicate that nicotine and nicotine analogues have potential to inhibit TLR2mediated inflammation in response to common agonists in

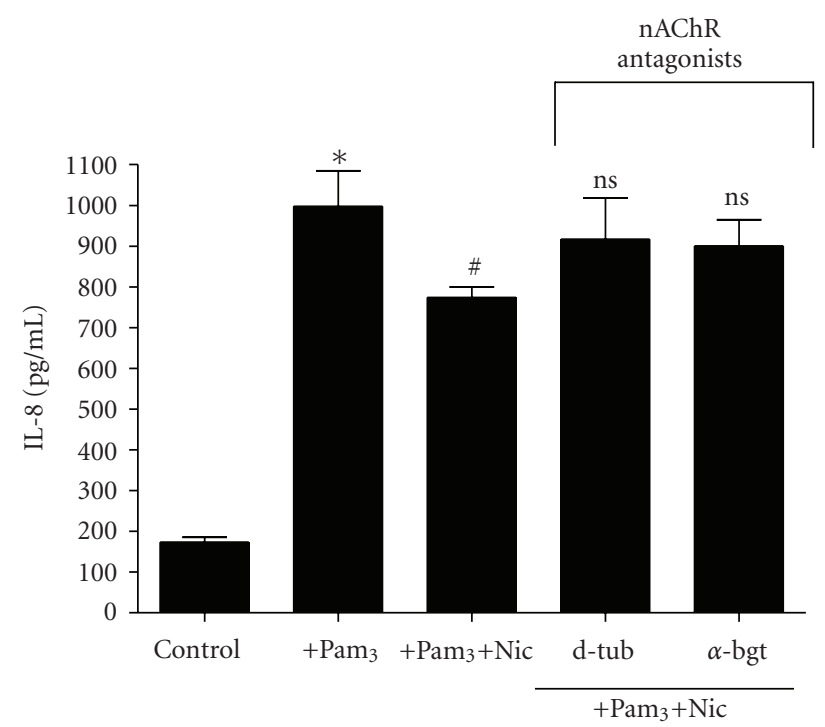

FIGURE 7: Inhibition of $\alpha 7-n A C h R$ abrogates nicotine's anti-TLR2 inhibitory effect. CFTE29o- cells $\left(1 \times 10^{5} / \mathrm{mL}\right)$ were left untreated or treated d-tubocurarine (d-tub, $100 \mu \mathrm{M})$ or $\alpha$-bungarotoxin $(\alpha$-bgt, $1 \mu \mathrm{M}$ ) for $16 \mathrm{~h}$. Nicotine was added as indicated at $10 \mu \mathrm{M}$ for 1 hour. Following this, some samples were stimulated with $\mathrm{Pam}_{3}(1 \mu \mathrm{g} / \mathrm{mL}$, 24 hours) and levels of IL- 8 in supernatants were measured by ELISA ( $*$ and ${ }^{\#} P \leq .05$, $*$ versus control, \# or ns versus $\mathrm{Pam}_{3}$ ). Assays were performed in triplicate $(n=3)$.

the CF lung via $\alpha 7-n A C h R$. These useful effects occur at dose levels that could be delivered to CF lungs through inhaled preparations.

\section{Acknowledgments}

The authors acknowledge the funding from The Health Research Board via their Summer Student Scholarship Scheme and PhD Scholar's Programme in Diagnostics and Therapeutics for Human Disease awarded to RCSI in 2007. C. M. Greene and H. Ramsay contributed equally to this work.

\section{References}

[1] P. B. Davis, M. Drumm, and M. W. Konstan, "Cystic fibrosis," American Journal of Respiratory and Critical Care Medicine, vol. 154, no. 5, pp. 1229-1256, 1996.

[2] J. F. Chmiel, M. Berger, and M. W. Konstan, "The role of inflammation in the pathophysiology of CF lung disease," Clinical Reviews in Allergy and Immunology, vol. 23, no. 1, pp. 5-27, 2002.

[3] C. M. Greene, T. P. Carroll, S. G. J. Smith, et al., "TLR-induced inflammation in cystic fibrosis and non-cystic fibrosis airway epithelial cells," Journal of Immunology, vol. 174, no. 3, pp. 1638-1646, 2005.

[4] K. Takeda and S. Akira, "TLR signaling pathways," Seminars in Immunology, vol. 16, no. 1, pp. 3-9, 2004.

[5] L. A. J. O’Neill, "How Toll-like receptors signal: what we know and what we don't know," Current Opinion in Immunology, vol. 18, no. 1, pp. 3-9, 2006. 
[6] M. Colonna, "TLR pathways and IFN-regulatory factors: to each its own," European Journal of Immunology, vol. 37, no. 2, pp. 306-309, 2007.

[7] C. M. Greene and N. G. McElvaney, "Toll-like receptor expression and function in airway epithelial cells," Archivum Immunologiae et Therapiae Experimentalis, vol. 53, no. 5, pp. 418-427, 2005.

[8] J. Platz, C. Beisswenger, A. Dalpke, et al., "Microbial DNA induces a host defense reaction of human respiratory epithelial cells," Journal of Immunology, vol. 173, no. 2, pp. 1219-1223, 2004.

[9] M. N. Becker, G. Diamond, M. W. Verghese, and S. H. Randell, "CD14-dependent lipopolysaccharide-induced $\beta$-defensin-2 expression in human tracheobronchial epithelium," Journal of Biological Chemistry, vol. 275, no. 38, pp. 29731-29736, 2000.

[10] M. M. Monick, T. O. Yarovinsky, L. S. Powers, et al., "Respiratory syncytial virus up-regulates TLR4 and sensitizes airway epithelial cells to endotoxin," Journal of Biological Chemistry, vol. 278, no. 52, pp. 53035-53044, 2003.

[11] C. J. Hertz, Q. Wu, E. M. Porter, et al., "Activation of Toll-like receptor 2 on human tracheobronchial epithelial cells induces the antimicrobial peptide human $\beta$ defensin-2," Journal of Immunology, vol. 171, no. 12, pp. 6820-6826, 2003.

[12] L. Guillott, S. Medjane, K. Le-Barillec, et al., "Response of human pulmonary epithelial cells to lipopolysaccharide involves Toll-like receptor 4 (TLR4)-dependent signaling pathways: evidence for an intracellular compartmentalization of TLR4," Journal of Biological Chemistry, vol. 279, no. 4, pp. 2712-2718, 2004.

[13] Y. Gon, Y. Asai, S. Hashimoto, et al., "A20 inhibits Tolllike receptor 2- and 4-mediated interleukin-8 synthesis in airway epithelial cells," American Journal of Respiratory Cell and Molecular Biology, vol. 31, no. 3, pp. 330-336, 2004.

[14] H. P. Jia, J. N. Kline, A. Penisten, et al., "Endotoxin responsiveness of human airway epithelia is limited by low expression of MD-2," American Journal of Physiology, vol. 287, no. 2, pp. L428-L437, 2004.

[15] O. Bachar, M. Adner, R. Uddman, and L.-O. Cardell, “Toll-like receptor stimulation induces airway hyper-responsiveness to bradykinin, an effect mediated by JNK and NF- $\kappa$ B signaling pathways," European Journal of Immunology, vol. 34, no. 4, pp. 1196-1207, 2004.

[16] L. Armstrong, A. R. L. Medford, K. M. Uppington, et al., "Expression of functional Toll-like receptor-2 and -4 on alveolar epithelial cells," American Journal of Respiratory Cell and Molecular Biology, vol. 31, no. 2, pp. 241-245, 2004.

[17] A. Muir, G. Soong, S. Sokol, et al., "Toll-like receptors in normal and cystic fibrosis airway epithelial cells," American Journal of Respiratory Cell and Molecular Biology, vol. 30, no. 6, pp. 777-783, 2004.

[18] X. Wang, Z. Zhang, J. P. Louboutin, C. Moser, D. J. Weiner, and J. M. Wilson, "Airway epithelia regulate expression of human beta-defensin 2 through Toll-like receptor 2," The FASEB Journal, vol. 17, no. 12, pp. 1727-1729, 2003.

[19] R. Adamo, S. Sokol, G. Soong, M. I. Gomez, and A. Prince, "Pseudomonas aeruginosa flagella activate airway epithelial cells through asialoGM1 and Toll-like receptor 2 as well as Toll-like receptor 5," American Journal of Respiratory Cell and Molecular Biology, vol. 30, no. 5, pp. 627-634, 2004.

[20] G. Soong, B. Reddy, S. Sokol, R. Adamo, and A. Prince, “TLR2 is mobilized into an apical lipid raft receptor complex to signal infection in airway epithelial cells," Journal of Clinical Investigation, vol. 113, no. 10, pp. 1482-1489, 2004.
[21] T. Homma, A. Kato, N. Hashimoto, et al., "Corticosteroid and cytokines synergistically enhance Toll-like receptor 2 expression in respiratory epithelial cells," American Journal of Respiratory Cell and Molecular Biology, vol. 31, no. 4, pp. 463469, 2004.

[22] Q. Sha, A. Q. Truong-Tran, J. R. Plitt, L. A. Beck, and R. P. Schleimer, "Activation of airway epithelial cells by Toll-like receptor agonists," American Journal of Respiratory Cell and Molecular Biology, vol. 31, no. 3, pp. 358-364, 2004.

[23] L. Guillot, R. Le Goffic, S. Bloch, et al., "Involvement of Tolllike receptor 3 in the immune response of lung epithelial cells to double-stranded RNA and influenza A virus," Journal of Biological Chemistry, vol. 280, no. 7, pp. 5571-5580, 2005.

[24] T. P. Carroll, C. M. Greene, C. C. Taggart, A. G. Bowie, S. J. O’Neill, and N. G. McElvaney, "Viral inhibition of IL-1and neutrophil elastase-induced inflammatory responses in bronchial epithelial cells," Journal of Immunology, vol. 175, no. 11, pp. 7594-7601, 2005.

[25] C. M. Greene, P. Branagan, and N. G. McElvaney, "Tolllike receptors as therapeutic targets in cystic fibrosis," Expert Opinion on Therapeutic Targets, vol. 12, no. 12, pp. 1481-1495, 2008.

[26] D. A. Scott and M. Martin, "Exploitation of the nicotinic anti-inflammatory pathway for the treatment of epithelial inflammatory diseases," World Journal of Gastroenterology, vol. 12, no. 46, pp. 7451-7459, 2006.

[27] R. De Simone, M. A. Ajmone-Cat, D. Carnevale, and L. Minghetti, "Activation of $\alpha 7$ nicotinic acetylcholine receptor by nicotine selectively up-regulates cyclooxygenase- 2 and prostaglandin E2 in rat microglial cultures," Journal of $\mathrm{Neu}$ roinflammation, vol. 2, article 4, 2005.

[28] L. Romics Jr., G. Szabo, J. C. Coffey, H. W. Jiang, and H. P. Redmond, "The emerging role of Toll-like receptor pathways in surgical diseases," Archives of Surgery, vol. 141, no. 6, pp. 595-601, 2006.

[29] D.-J. Li, Q. Tang, F.-M. Shen, D.-F. Su, J.-L. Duan, and T. Xi, "Overexpressed $\alpha 7$ nicotinic acetylcholine receptor inhibited proinflammatory cytokine release in NIH3T3 cells," Journal of Bioscience and Bioengineering, vol. 108, no. 2, pp. 85-91, 2009.

[30] S.-Y. Park, Y. H. Baik, J. H. Cho, S. Kim, K.-S. Lee, and J.-S. Han, "Inhibition of lipopolysaccharide-induced nitric oxide synthesis by nicotine through S6K1-p42/44 MAPK pathway and STAT3 (Ser 727) phosphorylation in Raw 264.7 cells," Cytokine, vol. 44, no. 1, pp. 126-134, 2008.

[31] H. K. Takahashi, H. Iwagaki, R. Hamano, T. Yoshino, N. Tanaka, and M. Nishibori, "Effect of nicotine on IL-18initiated immune response in human monocytes," Journal of Leukocyte Biology, vol. 80, no. 6, pp. 1388-1394, 2006.

[32] A. Karlin, "Emerging structure of the nicotinic acetylcholine receptors," Nature Reviews Neuroscience, vol. 3, no. 2, pp. 102114, 2002.

[33] Y. Wang, E. F. R. Pereira, A. D. J. Maus, et al., "Human bronchial epithelial and endothelial cells express $\alpha 7$ nicotinic acetylcholine receptors," Molecular Pharmacology, vol. 60, no. 6, pp. 1201-1209, 2001.

[34] C. M. Greene, G. Meachery, C. C. Taggart, et al., "Role of IL18 in $\mathrm{CD}^{+} \mathrm{T}$ lymphocyte activation in sarcoidosis," Journal of Immunology, vol. 165, no. 8, pp. 4718-4724, 2000.

[35] C. Greene, G. Lowe, C. Taggart, P. Gallagher, N. McElvaney, and S. O'Neill, “Tumor necrosis factor- $\alpha$-converting enzyme: its role in community-acquired pneumonia," Journal of Infectious Diseases, vol. 186, no. 12, pp. 1790-1796, 2002. 
[36] J. M. Devaney, C. M. Greene, C. C. Taggart, T. P. Carroll, S. J. O'Neill, and N. G. McElvaney, "Neutrophil elastase upregulates interleukin-8 via Toll-like receptor 4," FEBS Letters, vol. 544, no. 1-3, pp. 129-132, 2003.

[37] S. Griffin, C. C. Taggart, C. M. Greene, S. O’Neill, and N. G. McElvaney, "Neutrophil elastase up-regulates human $\beta$ defensin-2 expression in human bronchial epithelial cells," FEBS Letters, vol. 546, no. 2-3, pp. 233-236, 2003.

[38] C. M. Greene, N. G. McElvaney, S. J. O’Neill, and C. C. Taggart, "Secretory leucoprotease inhibitor impairs Toll-like receptor 2- and 4-mediated responses in monocytic cells," Infection and Immunity, vol. 72, no. 6, pp. 3684-3687, 2004.

[39] R. E. MacRedmond, C. M. Greene, C. T. Taggart, N. G. McElvaney, and S. O'Neill, "Respiratory epithelial cells require Toll-like receptor 4 for induction of human $\beta$-defensin 2 by lipopolysaccharide," Respiratory Research, vol. 6, article 116, 2005.

[40] N. T. Stevens, I. Sadovskaya, S. Jabbouri, et al., "Staphylococcus epidermidis polysaccharide intercellular adhesin induces IL-8 expression in human astrocytes via a mechanism involving TLR2," Cellular Microbiology, vol. 11, no. 3, pp. 421-432, 2009.

[41] K. Aoshiba, A. Nagai, S. Yasui, and K. Konno, "Nicotine prolongs neutrophil survival by suppressing apoptosis," Journal of Laboratory and Clinical Medicine, vol. 127, no. 2, pp. 186-194, 1996.

[42] W. L. Heusch and R. Maneckjee, "Signalling pathways involved in nicotine regulation of apoptosis of human lung cancer cells," Carcinogenesis, vol. 19, no. 4, pp. 551-556, 1998.

[43] R. Maneckjee and J. D. Minna, "Opioids induce while nicotine suppresses apoptosis in human lung cancer cells," Cell Growth and Differentiation, vol. 5, no. 10, pp. 1033-1040, 1994.

[44] T. Utsumi, K. Shimoke, S. Kishi, H. Sasaya, T. Ikeuchi, and H. Nakayama, "Protective effect of nicotine on tunicamycininduced apoptosis of PC12h cells," Neuroscience Letters, vol. 370, no. 2-3, pp. 244-247, 2004.

[45] H. Wang, M. Yu, M. Ochani, et al., "Nicotinic acetylcholine receptor $\alpha 7$ subunit is an essential regulator of inflammation," Nature, vol. 421, no. 6921, pp. 384-388, 2003.

[46] N. Sugano, K. Shimada, K. Ito, and S. Murai, "Nicotine inhibits the production of inflammatory mediators in U937 cells through modulation of nuclear factor- $\kappa \mathrm{B}$ activation," Biochemical and Biophysical Research Communications, vol. 252, no. 1, pp. 25-28, 1998.

[47] M. Laan, S. Bozinovski, and G. P. Anderson, "Cigarette smoke inhibits lipopolysaccharide-induced production of inflammatory cytokines by suppressing the activation of activator protein-1 in bronchial epithelial cells," Journal of Immunology, vol. 173, no. 6, pp. 4164-4170, 2004.

[48] H. Wang, H. Liao, M. Ochani, et al., "Cholinergic agonists inhibit HMGB1 release and improve survival in experimental sepsis," Nature Medicine, vol. 10, no. 11, pp. 1216-1221, 2004.

[49] R. W. Saeed, S. Varma, T. Peng-Nemeroff, et al., "Cholinergic stimulation blocks endothelial cell activation and leukocyte recruitment during inflammation," Journal of Experimental Medicine, vol. 201, no. 7, pp. 1113-1123, 2005.

[50] V. A. Pavlov, M. Ochani, L.-H. Yang, et al., "Selective $\alpha 7$ nicotinic acetylcholine receptor agonist GTS-21 improves survival in murine endotoxemia and severe sepsis," Critical Care Medicine, vol. 35, no. 4, pp. 1139-1144, 2007.
[51] D. Altavilla, S. Guarini, A. Bitto, et al., "Activation of the cholinergic anti-inflammatory pathway reduces NF- $\kappa \mathrm{B}$ activation, blunts TNF- $\alpha$ production, and protects against splanchnic artery occlusion shock," Shock, vol. 25, no. 5, pp. 500-506, 2006.

[52] O. Dowling, B. Rochelson, K. Way, Y. Al-Abed, and C. N. Metz, "Nicotine inhibits cytokine production by placenta cells via NF $\kappa$ B: potential role in pregnancy-induced hypertension," Molecular Medicine, vol. 13, no. 11-12, pp. 576-583, 2007.

[53] Q. Liu, J. Zhang, H. Zhu, C. Qin, Q. Chen, and B. Zhao, "Dissecting the signaling pathway of nicotine-mediated neuroprotection in a mouse Alzheimer disease model," FASEB Journal, vol. 21, no. 1, pp. 61-73, 2007.

[54] H. Yoshikawa, M. Kurokawa, N. Ozaki, et al., "Nicotine inhibits the production of proinflammatory mediators in human monocytes by suppression of $\mathrm{I}-\kappa \mathrm{B}$ phosphorylation and nuclear factor- $\kappa \mathrm{B}$ transcriptional activity through nicotinic acetylcholine receptor $\alpha 7$," Clinical and Experimental Immunology, vol. 146, no. 1, pp. 116-123, 2006.

[55] X. Su, J. W. Lee, Z. A. Matthay, et al., "Activation of the $\alpha 7 \mathrm{nAChR}$ reduces acid-induced acute lung injury in mice and rats," American Journal of Respiratory Cell and Molecular Biology, vol. 37, no. 2, pp. 186-192, 2007.

[56] A. Mazurov, T. Hauser, and C. H. Miller, "Selective $\alpha 7$ nicotinic acetylcholine receptor ligands," Current Medicinal Chemistry, vol. 13, no. 13, pp. 1567-1584, 2006.

[57] M. Rosas-Ballina, R. S. Goldstein, M. Gallowitsch-Puerta, et al., "The selective $\alpha 7$ agonist GTS-21 attenuates cytokine production in human whole blood and human monocytes activated by ligands for TLR2, TLR3, TLR4, TLR9, and RAGE," Molecular Medicine, vol. 15, no. 7-8, pp. 195-202, 2009.

[58] K. B. Mihalak, F. I. Carroll, and C. W. Luetje, "Varenicline is a partial agonist at $\alpha 4 \beta 2$ and a full agonist at $\alpha 7$ neuronal nicotinic receptors," Molecular Pharmacology, vol. 70, no. 3, pp. 801-805, 2006. 


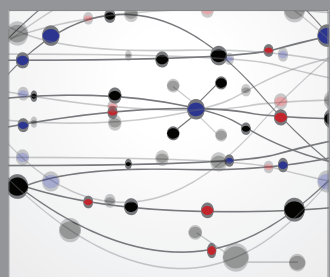

The Scientific World Journal
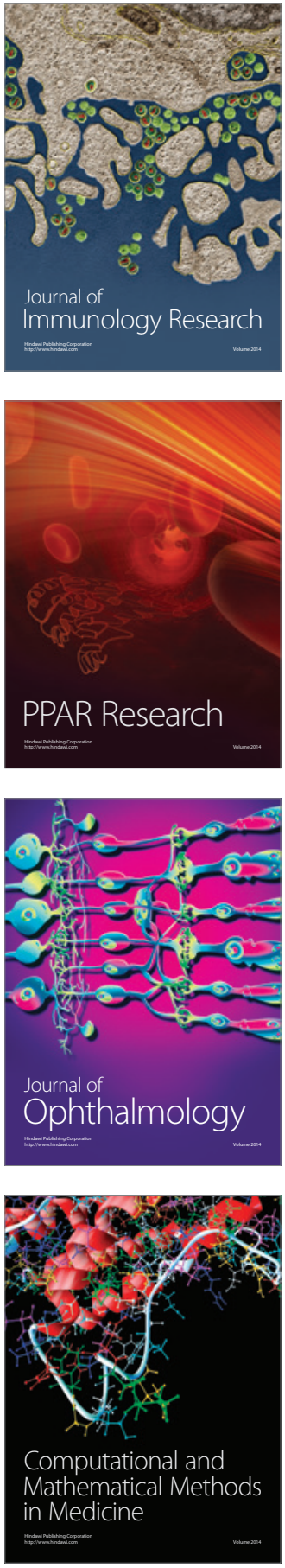

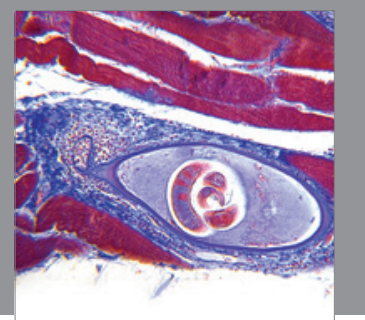

Gastroenterology

Research and Practice
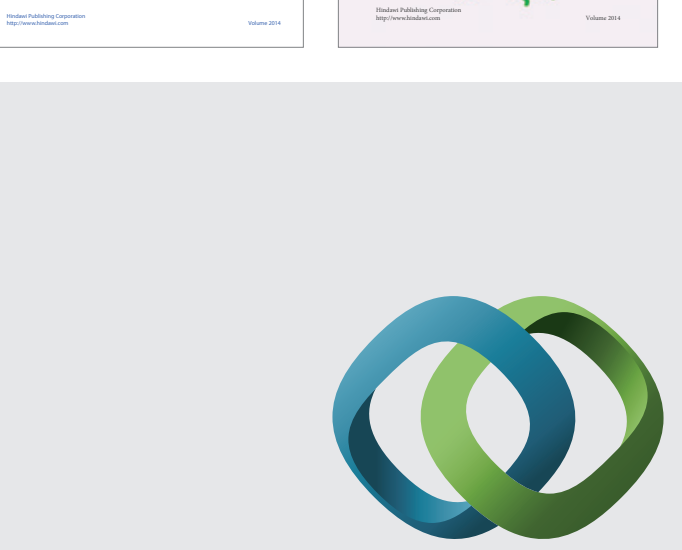

\section{Hindawi}

Submit your manuscripts at

http://www.hindawi.com
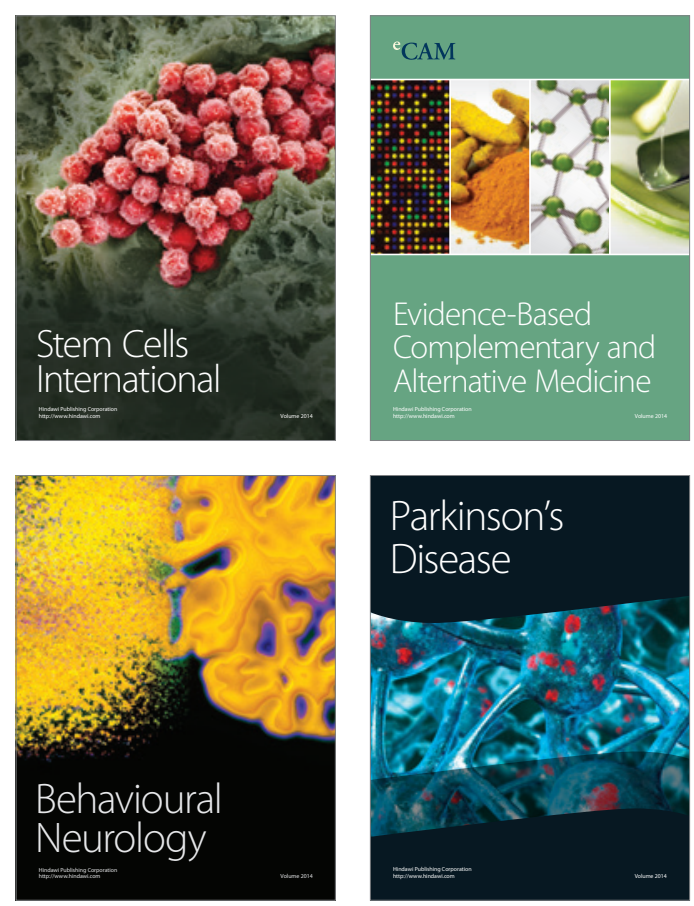

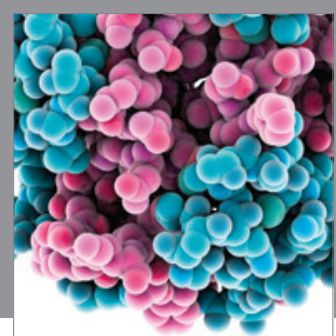

Journal of
Diabetes Research

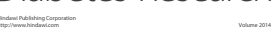

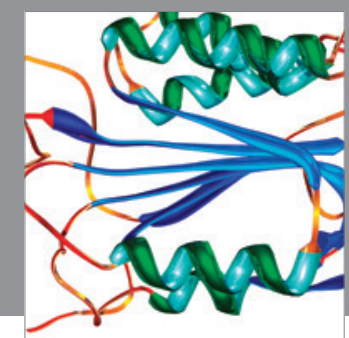

Disease Markers
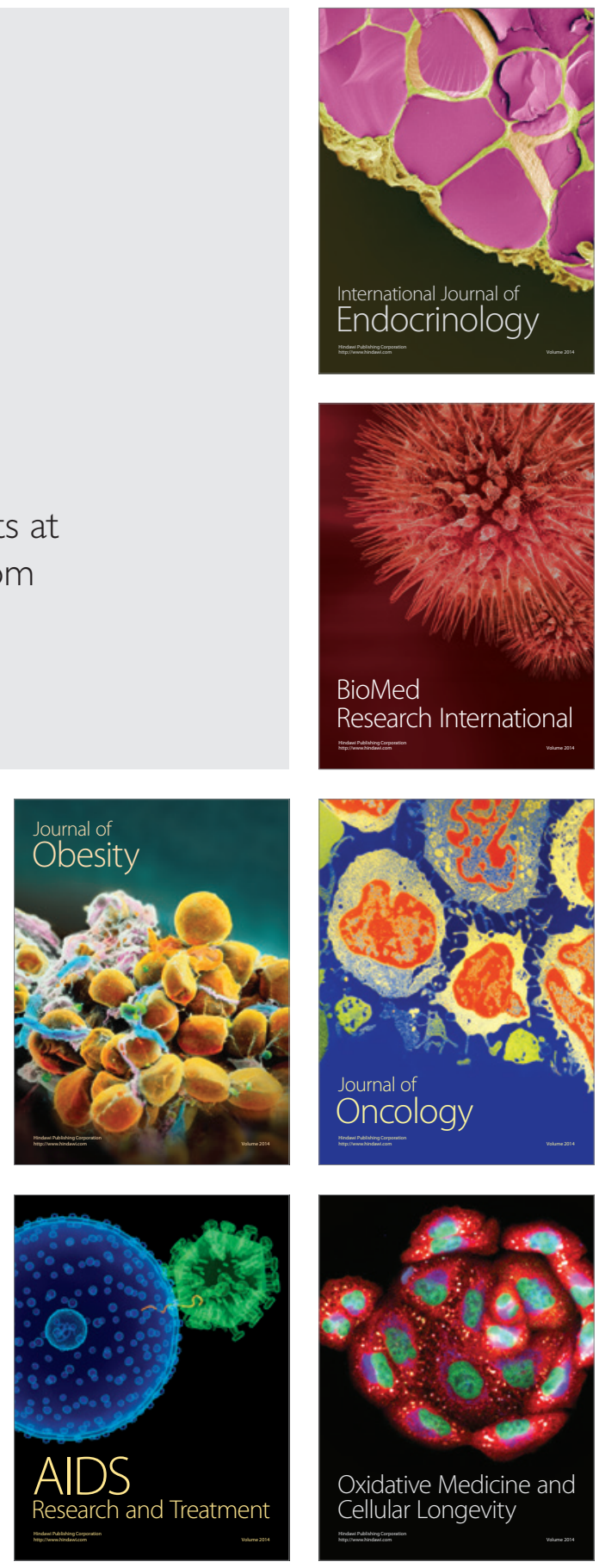